\title{
CYP1A1 GENE POLYMORPHISM AND NASOPHARYNGEAL CARCINOMA IN ALGERIAN POPULATION
}

\author{
Djekrif Ghania ${ }^{1, *}$, Bendjemana Katia ${ }^{1}$, Satta Dalila ${ }^{2}$ \\ ${ }^{1}$ Mentouri University, Constantine, Life and Scientific Faculty, Biology Department, Constantine, Algeria \\ ${ }^{2}$ Abbes Laghrour University, Faculty of Life and Scientific, Department of Biology, Khenchela, Algeria
}

\section{Current Trends in}

\section{Natural Sciences}

\begin{abstract}
CYP1A1 polymorphisms are known to play a crucial role in the development and metastasis of malignant diseases including nasopharyngeal cancer (NPC). Individual susceptibility to cancer from environmental agents may be influenced by polymorphic metabolic gene (CYPIA1). The present study was carried out to analyze the relationship between CYPIAl genetic polymorphism and the risk of developing nasopharyngeal cancer (NPC). The study involved 70 patients with nasopharyngeal carcinoma, compared with 100 healthy controls. Genomic DNA samples were assayed for restriction fragment length polymorphisms in the CYPIAl by PCR amplification followed by digestion with MspI and BsrDI. The frequency comparison between the two groups was determined by the $\chi(2)$ test. Showed that the distribution of CYP1A1 mt/mt allele frequency was found to be significantly different between controls (6\%) and cancer cases (11\%) along with twice increase of the NPC risk in Algeria (OR=2.5, CI 95\% [1.72-2.30])

Our results are in line with those found for other populations and subsequent they emphasize the importance of the involvement of this gene in the development of the NPC detoxification process, which exhibited more and more strong association with environmental factors.
\end{abstract}

Keywords: Algeria Population, Cytochrome P450 1A1, Genetic polymorphism, MspI, Nasopharyngeal carcinoma.

\section{INTRODUCTION}

Nasopharyngeal cancer (NPC) is a rare cancer in most parts of the world (Amal Chandra et al., 2010) with annual age-standardized incidence rates typically below 1 per 100,000 people/year, in both sexes (Parkin et al., 1992), but occurs at relatively high rates in some geographic regions and among certain ethnic groups with the highest incidence (Allan et al., 1997; Laantri et al., 2011). The distinct geographical and ethnic distribution of NPC seems to be associated with certain environmental and hereditary factors (Ju-Hong et al., 2004).

NPC development depends on either environmental risk factors or genetic susceptibility, or a combination of these two (Oliveira et al., 2006). Metabolic enzymes have a vital position on the axis of environment-gene interactions and carcinogenesis, because most carcinogens are activated or inactivated by detoxifying enzymes through metabolic processes (Luo et al., 2011). Genetic defects in metabolic enzymes thus affect the biotransformation of carcinogens and might contribute to cancer. The cytochrome P450 superfamily is a large and diverse group of enzymes that includes phase I biotransformation enzymes that catalyze the oxidation of organic substances. The substrates 
of CYP enzymes include metabolic intermediates such as lipids and steroidal hormones, as well as xenobiotic substances such as drugs and environmental chemicals (Guengerich, 2008).

Among the CYPs involved in procarcinogen activation, CYPIAl has been a major research focus. The CYP1A1 gene is located on 15q22 q14, encoding aryl hydrocarbon hydroxylase (AHH). AHH is a hepatic enzyme that catalyzes polycyclic aromatic hydrocarbons so that they become phenols and epoxides. Some of the phenols and epoxides may combine with DNA to form adducts. These DNA adducts are converted into the ultimate carcinogens. CYP1A1 has been shown to be the most important enzyme in the catalyzing activation of these procarcinogenic polycyclic aromatic hydrocarbons (Quiñones et al., 1995).

Several restriction fragment length polymorphism (RFLP) patterns in the CYPlAl gene have been identified; MspI and Ile/Val polymorphisms. It is widely accepted that the MspI polymorphism can cause an increase in AHH activation and mutagenic activity. Similarly, the Ile/Val polymorphism has been related to an increase in the activation of enzyme induction. The CYPlAl enzyme, also called the phase I metabolic enzyme, is a member of a large family of CYP enzymes that participate in the metabolism of endogenous and exogenous compounds, particularly polycyclic aromatic hydrocarbons such as benzo[a]pyrene (Guengerich et al., 1998), and is prone to mutation (Cheung et al., 2009).

The activation of the CYPlAl enzyme is related to the oxidation of endogenous and exogenous compounds and an increase in the toxicity of extraneous toxins and carcinogens. Hence, some variant genotypes of the CYPIAl gene may enhance enzymatic activity and influences the risk of several cancers (Rojas et al., 2000). However, whereas some studies report increased risk in the presence of some of the mutations (Wright et al., 1994; Lee et at., 2008), there are many other contradictory results due to ethnic differences (Pisani et al., 1992; Alexandrie et al., 2004).

In the present study, we examined the relationship between CYP1A1 genotypes and the risk of developing NPC pathogenesis within 70 NPC cases and 100 matched healthy controls from Algeria and to examine the interaction effect with Tobacco smoking in modulating disease risk. PCR and RFLP methods were used to identify polymorphisms in the gene of interest. MspI and BsrDI restriction enzymes digestions were utilized to detect genotypic polymorphisms. The use of these restriction enzymes was dictated by previous findings suggesting that the two forms of the gene detected by MspI and BsrDI digestions exhibit widely different levels of expression.

\section{MATERIALS AND METHODS}

\section{Study Population}

This study included 70 patients showing a confirmed histopathological case, untreated NPC. All patients are citizens of North East region of Algeria, as well as 100 healthy blood donors. The cases were recruited over a period extended from December; 2015 to May; 2016 at Dorban hospital (Annaba). Controls were frequency matched to the cases depending to age $( \pm 2 \mathrm{y})$, gender, and residence. In addition, Population controls were selected from a community screening program for early detection of cancer. At recruitment, each participant was personally interviewed, in order to obtain detailed information on ethnicity and family disease history sociodemographic characteristics, recent and prior tobacco use. Subjects were afterwards asked to consent to the collection of approximately $5 \mathrm{ml}$ blood; the 170 samples were taken with their consent and permission, we have obtained research agreement on human subjects in accordance with applicable laws. Blood samples were drawn with anti-coagulant (EDTA) tubes. 


\section{DNA extraction}

Genomic DNA was extracted from blood samples obtained from 100 controls and70 NPC patients using QIAamp DNA extraction kit (Qiagen Hilden, Germany, Cat no. 51304) according to the manufacturer's instructions.

\section{Genotyping of CYP1A1*2A and CYP1A1 *2C Polymorphisms}

Genomic DNA $(0.1 \mu \mathrm{g})$ extracted from whole blood was used for each PCR analysis. The $C Y P 1 A 1 * 2 C$ and $C Y P 1 A 1 * 2 A$ genotypes were analysed by PCR-based restriction fragment length polymorphism as described earlier with slight modification (Cascorbi et al., 1996; Shaffi et al., 2009; Wang et al., 2013) .

The primers used for $C Y P 1 A 1 * 2 C$ were $2 \mathrm{C}$ F-5'CAGTGAAGAGGTGTAGCCGCT-3' and 2C R-5'TTC CAC CCG TTG CAG CAG GAT AGC C-3'while the primers used for CYP1A1*2A were 2AF-5' GGCTGAGCAATCTGACCCTA-3' and 2AR-5' TAGGAGTCTTGTCTCATGCCT3'. The $2 \mathrm{CF}$ and $2 \mathrm{CR}$ primers generated a product of $195 \mathrm{bp}$, while $2 \mathrm{AF}$ and $2 \mathrm{AR}$ generated a 340 bp product. Each PCR performed with a total reaction volume of $25 \mu \mathrm{l}$ in PCR tube of 250 containing each: $100 \mathrm{ng}$ of DNA template, $10 \mathrm{mM}$ Tris/ $\mathrm{HCl} \mathrm{pH} \mathrm{9.0,50} \mathrm{mM} \mathrm{KCl,} 0.1 \%$ Triton X$100,2 \mathrm{mM} \mathrm{MgCl} 2(1.5 \mathrm{mM}$ for $C Y P 1 A 1 * 2 A$ and $C Y P 1 A 1 * 2 C), 200 \mu \mathrm{M}$ of deoxynucleotide triphosphate, $1 \mu \mathrm{M}$ of each primer, and 0.2 units of Taq polymerase, and the final volume, afterwards was completed to $25 \mu \mathrm{l}$ with distilled water. PCR cycling conditions consisted of initial denaturation at $94{ }^{\circ} \mathrm{C}$ for $5 \mathrm{~min}$, followed by 30 cycles of denaturation at $94{ }^{\circ} \mathrm{C}$ for $30 \mathrm{~s}$, annealing at $60{ }^{\circ} \mathrm{C}$ for $30 \mathrm{~s}$ and extension at $72{ }^{\circ} \mathrm{C}$ for 30 s, followed by a final extension of 5 min at $72{ }^{\circ} \mathrm{C}$. The restriction enzyme MspI (Fermentas, Canada) was used to distinguish the CYP1Al*2A polymorphism as gain of an Msp1 restriction site occurs in the polymorphic allele. The wild-type CYP $1 A 1 * 2 A$ allele shows a single band representing the entire $340 \mathrm{bp}$ fragment, variant allele results in two fragments of 200 and $140 \mathrm{bp}$. CYP1Al*2C allele genotypes were identified using special BsrDI restriction site. Analysis of the BsrDI site by gel electrophoresis revealed (163 and 32 base pair) fragments for wild-type alleles (isoleucine) or a single 195-base pair fragment in case of mutation "valine". (163,195 and 32 base pair) fragment for heterozygous.

The restricted products were analyzed by electrophoresis on $2 \%$ agarose gel. Bands were visualized with an ultraviolet Tran's illuminator after ethidium bromide staining.

\section{Statistical analysis}

Pearson's x2 test was used to examine differences in distributions of genotypes studied between cases and controls. ORs with 95\% CIs calculated using unconditional logistic regression and adjusted for age, gender, smoking status, were used to determine the association between genotype of the CYP1Al gene and NPC development. The 95\% confidence interval (CI) was computed to determine the statistical significance of the findings. Statistical significance was declared if twosided $\mathrm{P}<0.05$ or if the $95 \%$ CI did not include unity. All statistical analysis was performed by SPSS (8.0) software.

\section{RESULTS AND DISCUSSION \\ Results}

This study included 70 patients with NPC cancer and 100 healthy controls. Table 1 shows the demographic characteristics of those subjects. The mean age of patients was $57 \mathrm{y}$ (range, 20-more than $56 \mathrm{y}) ; 85.71 \%$ of the patients were male. Comparable statistics for control subject's were53 y (range, 20- more than 56) and 66\% \% were male. The majority age of our patients and our control subjects ranges between 30 and 56 years. The frequency match on smoking status between patients 
and controls was more smokers presented in patients compared to controls ( $\mathrm{p}<0.05)$. (92.42\%) of the cancer cases were smokers since $(62 \%)$ of the controls were smokers. No family history of NPC cancer was observed among controls and patients.

Table 1. Demographic characteristics of the study subjects

\begin{tabular}{lcc}
\hline Variable & Patients \% $(\mathbf{n = 7 0})$ & Controls \% $(\mathbf{n}=\mathbf{1 0 0})$ \\
\hline Gender & $60(85.71)$ & $66(66.0)$ \\
Male & $10(14.28)$ & $34(34.0)$ \\
Female & & \\
Mean age (year) & $7(10.0)$ & $9(9.0)$ \\
$20-30$ & $37(52.85 \%$ & $51(51.0)$ \\
$30-56$ & $24(34.28)$ & $40(40.0)$ \\
+56 & $7(10.0)$ & $38(38.0)$ \\
smoking status & $63(92.42)$ & $62(62.0)$ \\
Current & & \\
Non-smoker & 12.85 & \\
Histological type & 84.85 & \\
differentiated & 2.85 & \\
Undifferentiated & & \\
Highly differentiated & & \\
\hline
\end{tabular}

The results of genotype distribution of $C Y P 1 A 1 * 2 A$ and $C Y P 1 A 1 * 2 C$ displayed three genotypes with variable ratios in patients with NPC and in the control group (Table 2). These results showed that $11 \%$ of patients with NPC were carriers of $(\mathrm{mt} / \mathrm{mt})$ mutant genotypes of $C Y P 1 A * 2 A$, which was significantly higher than that observed in the control group $(6 \%)(\mathrm{OR}=2.5 ; 95 \% \mathrm{CI}[1.72-2.3])$. Subjects with $(\mathrm{mt} / \mathrm{mt})$ mutant genotype had a 2.5 -fold increased risk of developing nasopharynx Carcinoma compared with subjects with the wild-type and heterozygous ((wt/mt) and (wt/mt)) genotypes. No significant associations of the $C Y P 1 A l * 2 C$ genotype examined with NPC risk were noticed.

Table 2. Association between the CYP1A1*2A and CYP1A1*2C genotype and allele frequencies and NPC risk among patients and healthy

\begin{tabular}{|c|c|c|c|c|}
\hline Frequency & $\begin{array}{l}\text { Patients } \\
(n=70)\end{array}$ & $\begin{array}{l}\text { Controls } \\
(n=100)\end{array}$ & $\mathbf{P}$ & OR $(95 \%$ CI $)$ \\
\hline \multicolumn{5}{|c|}{ CYP1A1 genotype } \\
\hline \multicolumn{5}{|l|}{ CYP1A1 $* 2 A$} \\
\hline wt/wt & (41.0) $58 \%$ & (63.0) $63 \%$ & & $\mathbf{1}$ \\
\hline $\mathrm{wt} / \mathrm{mt}$ & (21.0) $30 \%$ & (31.0) $31 \%$ & & $1.2[0.7-1.8]$ \\
\hline $\mathrm{mt} / \mathrm{mt}$ & (8.0) $11 \%$ & (6.0) $6 \%$ & $\mathrm{p}<0.05$ & $2.5[1.72-2.3]$ \\
\hline \multicolumn{5}{|l|}{ CYP1A1*2C } \\
\hline $\mathrm{wt} / \mathrm{wt}$ & (30) $42.85 \%$ & (42) $42 \%$ & & $1.6[0.3-9.7]$ \\
\hline $\mathrm{wt} / \mathrm{mt}$ & (28) $40 \%$ & (44.0) $44 \%$ & & $1.5[0.91-2.68]$ \\
\hline $\mathrm{mt} / \mathrm{mt}$ & (12) $17.17 \%$ & (16.0) $16 \%$ & & $1.1[0.4-3.1]$ \\
\hline \multicolumn{5}{|c|}{ Allele frequency } \\
\hline \multicolumn{5}{|c|}{ For $C Y P 1 A 1 * 2 A$} \\
\hline Wild-type & 0.73 & 0.78 & & \\
\hline Mutant & 0.26 & 0.21 & & \\
\hline
\end{tabular}




\section{Current Trends in Natural Sciences}

Vol. 9, Issue 18, pp. 218-225, 2020

https://doi.org/10.47068/ctns.2020.v9i18.030

Current Trends in Natural Sciences (on-line)

ISSN: 2284-953X

Current Trends in Natural Sciences (CD-Rom)

ISSN: 2284-9521

ISSN-L: 2284-9521

ISSN-L: 2284-9521

The risk of NPC related $C Y P 1 A 1 * 2 A$ polymorphisms were ascertained between smoking and nonsmoking patients (Table 3$)$. The results show a significant excessive risk $(\mathrm{OR}=1.41 ; 95 \% \mathrm{CI}=$ $0.90-1.88$ ) related to smoking only among those with at least one copy of the CYP1A1*2A mutant allele compared with non_smoking population. We observed a strong significant modification of the $C Y P 1 A 1$ effect by smoking status. Among smokers, individuals homozygous for the CYPlAl $(\mathrm{mt} / \mathrm{mt})$ were at a 3.21-fold increased risk of disease relative to nonsmokers homozygous for the CYP1Al wild-type allele $(\mathrm{OR}=0.7 ; 95 \% \mathrm{CI}=0.2-2.3)$.

Table 3. Joint effect of CYP1A1 genotypic variants detected by MspI digestion and cigarette smoking on NPC

\begin{tabular}{|l|l|l|l|l|l|l|}
\hline Smoking & $\mathbf{w t / w t}$ & $\mathbf{O R}(\mathbf{9 5 \%}$ CI) & $\mathbf{w t / m t}$ & $\mathbf{O R}$ (95\% CI) & $\mathbf{m t} / \mathbf{m t}$ & OR (95\% CI) \\
\hline & $\begin{array}{l}\text { No. of patients / } \\
\text { No. of controls }\end{array}$ & & $\begin{array}{l}\text { No. of patients/No. } \\
\text { of controls }\end{array}$ & & $\begin{array}{l}\text { No. of patients/ } \\
\text { No. of controls }\end{array}$ & \\
\hline Smokers & $38 / 40$ & $1.15(0.88-2.08)$ & $18 / 19$ & $1.41(0.90-1.88)$ & $7 / 3$ & $3.21(2.01-3.86)$ \\
\hline Nonsmokers & $3 / 23$ & $0.8(0.5-1.2)$ & $3 / 12$ & $1.0(0.6-1.4)$ & $3 / 3$ & $0.7(0.2-2.3)$ \\
\hline
\end{tabular}

Table 4. Joint effect of CYP1A1 genotypic variants detected by MspI digestion and age on NPC

\begin{tabular}{|l|l|l|l|l|l|l|}
\hline Age / year & wt/wt & OR (95\% CI) & wt/mt & OR (95\% CI) & mt/mt & OR (95\% CI) \\
\hline & $\begin{array}{l}\text { No. of patients } \\
\text { /No. of controls }\end{array}$ & & $\begin{array}{l}\text { No. of patients/No. of } \\
\text { controls }\end{array}$ & $\begin{array}{l}\text { No. of patients/ } \\
\text { No. of controls }\end{array}$ & \\
\hline $\mathbf{2 0 - 3 0}$ & $4 / 3$ & $1.01(0.42-2.42)$ & $2 / 4$ & $0.3(0.1-1.1)$ & $1 / 2$ & $1.9(0.6-6.1)$ \\
\hline $\mathbf{3 0 - 5 6}$ & $18 / 30$ & $1.1(0.3-4.0)$ & $17 / 20$ & $1.9(0.6-5.1)$ & $2 / 1$ & $3.9(1.88-5.99)$ \\
\hline $\mathbf{5 6 6}$ & $19 / 4$ & $0.95(1.25-2.38)$ & $4 / 2$ & $0.7(0.2-2.0)$ & $1 / 3$ & $1.91(1.01-2.31)$ \\
\hline
\end{tabular}

We also examined the effect of CYPIAl genotype separately for age (table 4). A stronger association between homozygosity of CYPlAl $\mathrm{mt} / \mathrm{mt}$ and nasopharyngeal carcinoma was observed among patients whose age ranges between 30 and 56 years old $(\mathrm{OR}=3.9 ; 95 \% \mathrm{CI}=1.88-5.99)$ compared with patients whose age is more than 56 years $(\mathrm{OR}=1.91 ; 95 \% \mathrm{CI}=1.01-2.31)$.

\section{Discussion}

Biotransformation reactions involved in xenobiotic metabolism have two phases: CYP450 enzymes are central to the phase I reaction (Hatagima, 2002). Polymorphisms in the genes for CYP450 enzymes are associated with susceptibility to metabolic defects. Defects in these enzymes affect detoxification of xenobiotics, including carcinogens. Individuals with genotypes that result in increased metabolic activation of carcinogens and decreased detoxification are considered to be more susceptible to environmental carcinogens, giving them higher risk of cancer development (Luo et al., 2011). Molecular epidemiology is a powerful tool for identifying genetic risk factors for disease, and understanding the risk factors could be helpful in understanding disease biology, as well as assessing the risk of cancer development. Smoking is a well-known cause of lung cancer. $C Y P$ enzymes have a potential role in metabolizing smoking components. CYPIAl is responsible for the metabolic activation of aryl hydrocarbon carcinogens, such as benzo (a) pyrene (Beresford et al., 1993). Some procarcinogen components from tobacco smoking, such as aromatic amines and polycyclic aromatic hydrocarbons, are also metabolically activated by CYP1A (Song et al., 2001). Studies have shown that Msp I polymorphisms of CYPIAl correlate with increased cancer susceptibility, and an interaction between the CYP1A1 polymorphism and smoking (Janvilisri, 2015). However, the associations vary with ethnicity of population and histological cancer type. 
Genetic variants in the CYP1Al gene investigated here can result in an enhancement of the CYP1Al activities (Singh et al., 2015).

In the present study, was a high frequency of CYPlAl MspI gene polymorphisms $(\mathrm{mt} / \mathrm{mt})$. A higher prevalence of the CYP1A1 homozygous mutant genotype was recorded among NPC patients compared to controls with an OR of 2.5 [95\% CI: 1.72-2.3], p <0.05.

Our results, confirms the association of increased risk of NPC with the CYP1A1*2A genotype and smoking status. The increased risk in men, observed in our work, contrary to what has been described in the Pakistan population, could to be explained by a difference in socio-cultural context and by the majority of males reported a history of smoking while very few women reported having ever smoked, and by a predominance of male smoking in our population. These associations are clearly explained by the biological role of this enzymes, because $C Y P 1 A 1$ activate procarcinogens to highly reactive intermediates, with the enzyme generated by the $C Y P 1 A 1 * 2 A$ alleles having higher activity on some toxic compounds than the wild allele (Cia et al., 1997).

Only one study reported that no association was observed between the CYP1A1-MspI polymorphism and NPC cancer risk in a group of Taiwan people, the study carried out by Yu-Juen Cheng, 2003. Few studies have examined simultaneously the association between genetic polymorphisms of CYP1A1- MspI and NPC. This is the first study to report an interaction of CYP1A1 polymorphism and environmental factors in the development of NPC in Algerian population. In the studies by Chatterjee et al (2009) and Chatterjee et al (2010), similar type of result, have been reported in oral cancers.

We also found a significant association between the homozygous mutant $(\mathrm{mt} / \mathrm{mt})$ genotype and age in our study, individuals in the 30-56y age group showed a strong association in the NPC in the presence of the homozygous mutant $(\mathrm{mt} / \mathrm{mt})$ genotype of the CYP1A1 (OR=3.7; 95\% IC $=1.78$ 5.96). This shows that an early exposure to tobacco would cause the expression of a number more important of cancer mutations. Such patients present factor genetic regulation of oncogenic expression.

The analysis of $C Y P 1 A 1$ gene, showed that the $C Y P 1 A 1 * 2 C$ is not a risk factor for NPC. The explanation of our data may reside in the fact that, in our sample, other genetic and / or environmental factors would be involved, for example other polymorphisms like; $C Y P 1 A 1 * 3$, $C Y P 1 A 1 * 4$ and $C Y P 1 A 1 * 1$. A larger sample size study including smokers is needed to unravel the complex interplay effects between gene polymorphisms and tobacco smoking and to compare between local environmental factors.

\section{CONCLUSION}

Results of this study showed a statistically significant association between the polymorphisms of $C Y P 1 A 1 * 2 C \mathrm{mt} / \mathrm{mt}$ genotype with the increased risk of NPC in Algeria. Moreover, this strong association at genotype and allele level was exacerbated among tobacco smoking with NPC, genetic susceptibility factors for nasopharyngeal carcinoma identified in our study could serve as useful biomarkers for targeting prevention of cancer.

\section{ACKNOWLEDGEMENTS}

We thank the president of hospital Dorban (Annaba), for his cooperation. We are also grateful to the medical staffs of hospital Dorban (Annaba), for their assistance in data collection, and Mentouri University Constantine for technical assistance. We would like to thank all the control subjects and patients who participated in this research study 


\section{Current Trends in Natural Sciences}

Vol. 9, Issue 18, pp. 218-225, 2020

https://doi.org/10.47068/ctns.2020.v9i18.030

Current Trends in Natural Sciences (on-line)

ISSN: 2284-953X

Current Trends in Natural Sciences (CD-Rom)

ISSN: 2284-9521

ISSN-L: 2284-9521

ISSN-L: 2284-9521

\section{REFERENCES}

Amal, Chandr,a K., Malcolm, J. S., Ashok, Kumar, Das, Kalpana, Sh., et al. (2011). Nasopharyngeal carcinoma in the Northeastern states of India. Chin J Cancer, 30, 106-113.

Parkin, D. M., Muir, C. S. (1992). Cancer Incidence in five continents: comparability and quality of data. IARC Sci Publ, 13, 145-173.

Allan, H., Lucy, M. A., Chien-Jen, Ch., Yu-Juen Ch., Louise, A. B., Ann, K. D., et al. (1997). CYP2E1 genetic polymorphisms and risk of nasopharyngeal carcinoma in taiwan. J Natl Cancer Inst, 89, 1208-1212.

Laantri, N., Marilys, C., Dardari, R., Benider, A., El Gueddar,i B., Khyatti, M. (2011). Environmental, genetic and viral risk factors of nasopharyngeal carcinoma in North Africa. Inst Pasteur Int Network Annual Sci Meeting Hong Kong, 5, 30 .

Ju-Hong, J., Hua, W., Kui, C. H., Bing-Jian, F. G., Hai- D. Q., Zhi-Gang, P., et al. (2004). Genetic polymorphisms of CYP2A13 and its relationship to nasopharyngeal carcinoma in the cantonese population. $J$ Translational Med, 2, 17-24.

Oliveira, C., Seruca, R., Carneiro, F. (2006). Genetics, pathology, and clinics of familial gastric cancer. Int J Surg Pathol, 14, 21-33.

Luo, Y. P., Chen, H. C., Khan, M. A., Chen, F. Z., Wan, X. X., Tan, B., Ou-Yang, F.D., Zhang, D.Z. (2011). Genetic polymorphisms. of metabolic enzymes-CYP1A1, CYP2D6, GSTM1, and GSTT1, andgastric carcinoma susceptibility. Tumor Biol, 32, 215-222.

Guengerich, F. P. (2008). Cytochrome p450 and chemical toxicology. Chem Res Toxicol, 21, 70-83.

Quiñones, L., Gil, L., (1995). Induction of rat hepatic cytochrome P450 1A1 isozyme by organic extracts from airborne particulate matter. Xenobiotica, 25, 571-579.

Guengerich, F.P., Shimad, A. T. (1998). Activation of procarcinogens by human cytochrome P450 enzymes. Mutat Res, 400, 201-213.

Cheung, W. Y., Liu, G. (2009). Genetic variations in esophageal cancer risk and prognosis. Gastroenterol Clin N, 38, 75-91.

Rojas, M., Cascorbi, I., Alexandrov, K., et al. (2000). Modulation of benzo[a] pyrene diolepoxide-DNA adduct levels in human white blood cells by CYP1A1, GSTM1 and GSTT1 polymorphism. Carcinogenesis, 21, 35-41.

Wright, C. M., Larsen, J. E., Colosimo, M. L., Barr, J. J., Chen, L., McLachlan, R. E., Yang, I.A., Wynder, E.L., Hoffmann, D. (1994). Smoking and lung cancer: scientific challenges and opportunities. Cancer Res, 54, 52845295.

Lee, K. M., Kang, D., Clapper, M. L., Ingelman-Sundberg, M., Ono-Kihara, M., Kiyohara, C., Min, S., Lan, Q., Le Marchand, L., et al. (2008). CYP1A1, GSTM1, and GSTT1 polymorphisms, smoking, and lung cancer risk in a poole analysis among Asian populations. Cancer Epidemiol Biomarkers Prev, 17, 1120-1126.

Alexandrie, A. K., Nyberg, F., Warholm , M., Rannug, A. (2004). Influence of CYP1A1, GSTM1, GSTT1, and NQO1 genotypes and cumulative smoking dose on lung cancer risk in a Swedish population. Cancer Epidemiol Biomarkers Prev, 13, 908-914.

Pisani, P., Srivatanakul, P., Randerson-Moor, J., Vipasrinimit, S., Lalitwongsa, S., Rautio, A., Kraul, H., Kojo, A., Salmela, E., Pelkonen, O. (1992). Interindividual variability of coumarin 7-hydroxylation in healthy volunteers.Pharmacogenetics, 2, 227-233.

Cascorbi, I., Brockmöller, J., Roots, I., (1996). A C4887A polymorphism in exon 7 ofhuman CYP1A1: population frequency, mutation linkages, and impact on lung cancer susceptibility. Cancer Res, 56, 4965-4969.

Shaffi, S. M., Shah, M. A., Bhat, I. A., Koul, P., Ahmad, S. N., Siddiqi, M. A. (2009). CYP1A1 polymorphisms and risk of lung cancer in the ethnic Kashmiri population. Asian Pac J Cancer Prev, 10, 651-656.

Wang, H., Wang, W. J. (2013). Relationship between CYP1A1 polymorphisms and invasion and metastasis of breast cancer. Asian Pac J Trop Med, 6, 835-838

Hatagima, A. (2002). Genetic polymorphisms and metabolism of endocrine disruptors in cancer susceptibility. Cad Saude Publica, 18, 357-377.

Luo, Y. P., Chen, H. C., Khan, M. A., Chen, F. Z., Wan, X. X., Tan, B., Ou-Yang, F. D., Zhang, D. Z. (2011). Geneticpolymorphisms of metabolic enzymes-CYP1A1, CYP2D6, GSTM1, and GSTT1, and gastric carcinoma susceptibility. Tumor Biol, 32 , 215-222.

Beresford, A. P. (2001). CYP1A1: friend or foe? .Drug Metab Rev, 25, 503-517.

Song, N., Tan, W., Xing, D., Lin, D. (2001). CYP1A1 polymorphism and risk of lung cancer in relation to tobacco smoking: a case-control study in China. Carcinogenesis, 22, 11-16. 


\section{Current Trends in Natural Sciences}

Vol. 9, Issue 18, pp. 218-225, 2020

https://doi.org/10.47068/ctns.2020.v9i18.030

Current Trends in Natural Sciences (on-line)

ISSN: 2284-953X

Current Trends in Natural Sciences (CD-Rom)

ISSN: 2284-9521

ISSN-L: 2284-9521

ISSN-L: 2284-9521

Janvilisri, T. (2015). Omics-based identification of biomarkers for nasopharyngeal car-cinoma. Dis Markers, 2015, 7621-7628.

Singh, S. A., Choudhury, J. H., Kapfo, W., Kundu, S. H., Dhar, B., Laskar, Sh., Das, R., Kumar, M., Ghosh, S. K. (2015). Influence of the CYP1A1 T3801C polymorphism on tobacco and alcohol-associated head and neck cancer susceptibility in Northeast India. Asian Pac J Cancer Prev, 16, 6953-6961.

Cai, L., Yu, S. Z. (1999). A molecular epidemiological study on gastric cancer in Changle, Fujian Province. World J Gastroenterol, 7, 652-655.

Cheng, Y. J., Chien, Y. Ch., Hildesheim, A., et al. (2003). No Association between genetic polymorphisms of cyp1a1, gstm1, gstt1, gstp1, nat2, and nasopharyngeal Carcinoma in Taiwan. Cancer Epidemiol Biomarkers Prev, 12, 179-180.

Young, C., Lo, Y., Tsai, Y., et al. (2010). CYP1A1 gene polymorphisms as a risk factor for pterygium. Mol Vis, 16, 1054-1058. 